\title{
Pemanfaatan Hasil Induksi Hormon Estrogen terhadap Kadar Estradiol dan Histologi Uterus Mencit (Mus musculus) Sebagai Buku Suplemen Sistem Reproduksi di SMA
}

\author{
Erlia Narulita, Jekti Prihatin, Ratna Sari Dewi
}

Progam Studi Pendidikan Biologi, FKIP, Universitas Jember
J1. Kalimantan 37, Jember, 68I18, Indonesia
surat elektronik: erlia.fkip@,unej.ac.id

\begin{abstract}
ABSTRAK
Synthetic estrogen hormone is well known as an hormonal contraception or birth control pills. The lack of public knowledge about the action mechanism of oral contraception on the reproductive organs makes people ignoring about the impact of it. This study was conducted to analyze the differences in the induction of estrogen towards the levels of estradiol and histology of the uterus and its utilization as a supplement book of Reproductive System topic in high school. Balb-C female mices were used as the tested animals and Microgynon, the contraceptive pill's trademark was used as a source of estrogen induces. Blood samples were taken at pro-estrus phase, while the uterus was taken at each phase of the estrous cycle. Measurement of estradiol levels was done by ELISA method, whereas the thickness of endometrium is determined on a longitudinal incision of the uterus by the method of preparation of histological paraffin and $H E$ staining. The supplement book was arranged refers to 4-D models. The research used six validators to assess the quality of the book and forty students to test the result of developmental book. Data was obtained from student and teacher questionnaires, validator sheets, questionnaires of the legitility and difficulty level, and student's response questionnaires. The data was analyzed by using percentage data analysis technique. The results showed that there was a difference between the levels of estradiol-induced estrogen treatment with control, but in endometrial thickness among the control treatment with estrogen did not show the differences significantly. The results also showed that the estrogen induction has no significant effect on endometrium thickness at each phases of estrous cycle. The result of development of supplemental book revealed that the book has been strong valid with 79,55\% score. It means that it can be used as supplement in learning process directly. Meanwhile $82,50 \%$ and $87,50 \%$ students gave positive respon as a result of the legitility and difficulty level, and student's response questionnaires, respectively. In conclusion, the result of induction estrogen towards estradiol and uterus histology can be used as supplemental book in reproductive system topic in SMA.
\end{abstract}

Kata kunci: estrogen, estradiol, uterus, buku suplemen.

\section{Pendahuluan}

Keluarga berencana (KB) adalah tindakan yang membantu individu atau pasangan suami istri untuk mendapatkan tujuan-tujuan tertentu, menghindari kelahiran yang tidak diinginkan, mendapatkan kelahiran yang memang diinginkan, mengatur interval di antara kehamilan, mengontrol waktu saat kelahiran dalam hubungan dengan umur suami isteri, dan menentukan jumlah anak dalam keluarga (WHO dalam Hartanto, 2004). Program keluarga berencana (KB) di Indonesia dijalankan dengan cara kontrasepsi yaitu upaya untuk mencegah terjadinya kehamilan (Info Sehat, 2008). Menurut data BKKBN (2007), metode KB yang digunakan oleh akseptor di Indonesia yaitu suntik $56,33 \%$, pil $24,87 \%$, sedangkan IUD $9,34 \%$, implant 3,03\%, dan kontrasepsi lainnya 5\%. Adapun jenis kontrasepsi oral (pil) dengan merk dagang Microgynon dikonsumsi oleh masyarakat Indonesia sebesar 61,76\% dari seluruh merk yang beredar di Indonesia (Nielsen dalam IPB, 20I0). Kontrasepsi oral Microgynon merupakan pil kombinasi yang mengandung 0,03 mg Ethinyl Estradiol dan 0,I5 mg Levonorgestrel (Hartanto, 2004).

Ethinyl Estradiol merupakan hormon sintetik dari estrogen. Estrogen merupakan salah satu hormon reproduksi pada hewan betina. Estrogen terdiri dari tiga jenis hormon yang berbeda, yaitu estron, estradiol, dan 
estriol (Anwar, 2005). Menurut Heffner dan Schust (2006), estradiol merupakan estrogen utama yang disekresi oleh ovarium. Estrogen meningkatkan aliran darah uterus dan mempunyai efek penting pada otot polos uterus (Ganong, 1999). Estrogen yang disekresikan dalam jumlah yang semakin meningkat oleh folikel yang sedang tumbuh, merupakan suatu sinyal hormonal ke uterus yang menyebabkan endometrium menebal (Campbell, 2004). Kadar estrogen yang berlebihan atau kurang, menyebabkan pola endometrium yang abnormal sehingga menjadi tidak baik untuk implantasi (Hartanto, 2004).

Hormon estrogen sintetik yang sudah dikenal oleh masyarakat adalah estrogen yang terkandung dalam pil kontrasepsi hormonal/ pil KB. Selama ini, masyarakat Indonesia hanya mengetahui macam-macam alat kontrasepsi berserta keuntungan dan kerugiannya, tanpa mengetahui mekanisme kerja dari pil KB terhadap organ reproduksi. Minimnya pengetahuan masyarakat tentang mekanisme kerja dari pil KB terhadap organ reproduksi membuat masyarakat tidak peduli dengan dampak yang ditimbulkan pada organ reproduksinya. Berbagai hormon estrogen yang sudah digunakan dalam beberapa penelitian dinyatakan memiliki pengaruh terhadap perubahan organ reproduksi mammalia. Namun selama ini penelitian-penelitian tersebut, belum pernah digunakan dan dipublikasikan kepada masyarakat, khususnya siswa Sekolah Menengah Atas (SMA) kelas XI semester genap dalam konsep sitem reproduksi sebagai salah satu media pembelajaran atau alternatif bahan ajar.

Salah satu alternatif media pembelajaran yang dapat digunakan dalam konsep sistem reproduksi adalah dengan menggunakan preparat uterus yang telah di induksi hormon estrogen. Adapun alternatif bahan ajar yang dapat digunakan adalah dengan menggunakan buku. Menurut Peraturan Menteri Pendidikan Nasional Nomor 2 tahun 2008 pasal 6 (2) yang menyatakan bahwa "selain buku teks pelajaran, pendidik dapat menggunakan buku panduan pendidik, buku pengayaan, dan buku referensi dalam proses pembelajaran". Berdasarkan ketentuan di atas maka terdapat empat jenis buku yang digunakan dalam bidang pendidikan, yaitu (I) Buku Teks Pelajaran; (2) Buku Pengayaan; (3) Buku Referensi; dan (4) Buku Panduan Pendidik. Untuk memudahkan dalam memberikan klasifikasi dan pengertian pada buku-buku pendidikan, dilakukan dua pengelompokan buku pendidikan yang ditentukan berdasarkan ruang lingkup kewenangan dalam pengendalian kualitasnya, yaitu (I) Buku Teks Pelajaran dan (2) Buku Nonteks Pelajaran (Pusat Perbukuan, 2008b).

Jika dicermati berdasarkan makna leksikal, buku nonteks pelajaran merupakan buku-buku yang tidak digunakan secara langsung sebagai buku untuk memelajari salah satu bidang studi pada lembaga pendidikan (Pusat Perbukuan, 2008b). Buku non teks dalam pengertian umum disebut juga sebagai buku suplemen atau buku tambahan untuk melengkapi buku acuan utama. Buku suplemen umumnya menggunakan bahasa yang mudah dipahami dan jangkauannya luas karena dapat diperoleh di berbagai toko buku sehingga masyarakat mudah untuk mendapatkannya. Hasil penelitin ini yang berupa histologi uterus dan pengaruh kontrasepsi hormonal dapat digunakan sebgai bahan buku suplemen biologi SMA untuk materi Sistem Reproduksi pada Manusia. Siswa perlu dibekali dengan pengetahuan reproduksi sejak dini termasuk di dalamnya tentang kontrasepsi hormonal, mengingat siswa dapat menjadi agen pendidik di masyarakat rumah dan lingkungan sekitarnya untuk menyebarkn manfaat dan dampak kontrasepsi hormonal.

\section{Metode Penelitian}

\section{Hewan Uji}

Hewan uji yang digunakan dalam penelitian ini adalah mencit betina dara (Mus musculus) strain BalbC, sebanyak 32 ekor, berumur 2 bulan, dengan berat 25 - 30 gram. Hewan uji dipelihara dalam kandang yang terbuat dari plastik dengan atap berupa ram kawat. Pakan dan minum hewan uji diberikan secara ad libitum. Pakan hewan uji berupa pellet merk dagang TURBO sedangkan air minum berupa air PAM. Pemeliharaan hewan uji dilakukan pada laboratorium dengan kondisi yang terkontrol dan konstan.

\section{Penginduksian Hormon Estrogen}

Hormon estrogen yang diinduksikan berasal dari pil kontrasepsi hormonal merk dagang Microgynon dengan cara gavage lambung setiap hari I kali sampai hari ke 5. Serial konsentrasi yang diberikan sebesar 0,26 mg yang diencerkan sampai $0,5 \mathrm{ml}$ dengan aquades sesuai dengan kapasitas lambung mencit (Anggara, 2009).

\section{Pengambilan dan Pengukuran Sampel Hormon}

Sampel darah untuk pengukuran hormon estradiol diambil pada fase proestrus. Masing-masing perlakuan dengan 3 kali ulangan. Sampel darah diambil langsung dari jantung, sesuai metoda Oduma et al. (dalam Sitasiwi, 2007). Pengukuran kandungan hormon dilakukan dengan metoda ELISA.

\section{Penentuan Tebal Endometrium Uterus}

Sampel uterus diambil pada setiap fase penyusun siklus estrus pada hari ke- 6 dan menggunakan hewan yang diambil sampel darahnya untuk pengukuran 
estradiol. Uterus dibuat sediaan histologis dengan pewarnaan HE dengan metoda parafin. Penentuan tebal endometrium dilakukan dengan menghitung rerata dari endometrium dengan ukuran tebal tertinggi, sedang dan terendah pada setiap sayatan uterus sampel (Rukmo, 1997). Pangamatan dan pengukuran dilakukan pada setiap 5 sayatan uterus pada setiap fase penyusun siklus estrus.

\section{Penyusunan Buku Suplemen}

Buku suplemen yang disusun berupa informasi dari hasil penelitian yang telah dilakukan yang disesuaikan dengan kebutuhan masyarakat khususnya siswa SMA. Penyusunan buku suplemen ini disesuaikan dengan model 4-D (Four-D models) yang telah dimodifikasi (Sumitro, 2008); yang terdiri dari tahap pendefinisian (define), tahap perancangan (design), tahap pengembangan (develop), dan tahap penyebaran (disseminate). Namun pada penelitian ini tahap penyebaran hanya dilakukan dalam skala terbatas.

\section{Analisis Data}

Data kadar estradiol dan histologi uterus yang diperoleh ditabulasikan dan dilakukan uji homogenitas. Selanjutnya dilakukan analisa dengan Independent Sample t-test untuk menguji perbedaan kadar estradiol dan tebal endometrium antara kontrol dan perlakuan estrogen dengan taraf signifikasi 5\%. Adapun untuk menguji pengaruh fase penyusun siklus estrus terhadap histologi uterus digunakan analisis One Way Anova dengan bantuan software SPSS versi 17.0. Jika hasil dari analisis uji tersebut berbeda nyata, maka dilanjutkan uji LSD dan Duncan dengan taraf signifikasi 5\%.

Adapun analisis kelayakan buku suplemen dilakukan dengan modifikasi model 4-D (Four-D models) dimana tahap penyebaran (disseminate), perangkat pembelajaran dilakukan secara terbatas. Validasi ahli yang akan menilai buku suplemen ini terdiri atas tiga orang ahli (materi dan media) dan tiga orang guru biologi dari tiga SMA Negeri di Kabupaten Jember yang telah memenuhi kriteria yang sudah ditetapkan oleh Pusat Perbukuan (2008). Rancangan buku selanjutnya diuji coba pada 40 siswa kelas XI SMA, dimana peneliti bertindak sebagai pengajar. Pada akhir kegiatan uji terbatas, siswa diminta mengisi angket keterbacaan dan tingkat kesulitan serta angket respon siswa terhadap bahan suplemen yang dikembangkan. Data uji keterbacaan dan uji kesulitan dianalisis secara deskriptif dengan menelaah hasil penilaian yang diberikan siswa terhadap buku siswa. Angket respon siswa digunakan untuk mengetahui pendapat siswa buku suplemen kontrol hormonal.

\section{Hasil dan Pembahasan \\ Perbedaan Kadar Estradiol dan Tebal Endometrium akibat Induksi Hormon Estrogen}

Estrogen merupakan hormon seks steroid yang berperan penting dalam pertumbuhan dan perkembangan seksual sekunder betina, seperti kelenjar mammae dan organ reproduksi yang lain (Dellman dan Brown, I992). Hormon estrogen yang digunakan merupakan hormon sintetik berupa etinyl estradiol. Estradiol merupakan bentuk hormon estrogen yang paling poten dan dijumpai dengan jumlah yang cukup tinggi dalam tubuh (Johnson dan Everitt dalam Sitasiwi, 2007; Dellman dan Brown, 1992; Ganong, 2003). Berdasarkan Tabel I dapat diketahui bahwa induksi hormon estrogen terhadap kadar estradiol memiliki nilai signifikasi sebesar 0,03 $(p<0,05)$ yang artinya terdapat perbedaan yang signifikan antara kadar estradiol yang terdapat pada mencit kontrol dengan mencit perlakuan. Hal tersebut diasumsikan karena dua persen estradiol beredar bebas di dalam darah, 60\% berikatan dengan albumin dan 38\% berikatan ke gonadal steroid binding globulin (GBG) yang juga mengikat testosteron (Ganong, 2003). Etinyl estradiol yang berikatan dengan protein pengangkut dalam darah yaitu albumin maupun globulin ini dapat dengan mudah masuk ke dalam sitoplasma sel (Murray et al, 2003).

Pada perlakuan, mencit mendapatkan induksi etinyl estradiol yang berasal dari pil kontrasepsi oral sehingga kadar estradiol yang masuk dalam tubuh dan berikatan dengan albumin maupun globulin lebih banyak dibandingkan kontrol. Estrogen sintetik yang masuk ke dalam tubuh akan menyebabkan kadar estradiol dalam darah semakin meningkat. Kerja progesteron untuk menekan kadar estradiol dalam darah akan mengalami kesulitan sebab sifat dari etinyl estradiol sintetik tersebut yang sulit untuk didegradasi. Turunan etinyl estradiol adalah suatu estrogen kuat dan relatif aktif bila diberikan per oral, karena resisten terhadap metabolisme hati (Ganong, 2003).

Tabel I. Hasil rerata kadar estradiol dan tebal endometrium karena induksi hormon estrogen

\begin{tabular}{lcc}
\hline Perlakuan & $\begin{array}{c}\text { Kadar Estradiol } \\
(\mathrm{pg} / \mathrm{mL})\end{array}$ & $\begin{array}{c}\text { Tebal endometrium } \\
(\mathrm{mm})\end{array}$ \\
\hline Kontrol & $44,69 \pm 3,97$ & $0,20 \pm 0,02$ \\
\hline Estrogen & $52,34 \pm 0,85$ & $0,2 \mathrm{I} \pm 0, \mathrm{I3}$ \\
\hline Signifikansi & $0,03^{\star}$ & $0,2 \mathrm{I}$ \\
\hline \multirow{2}{*}{ Menunjukkan tingkat signifikansi karena $\mathrm{p}<0,05$} \\
menggunakan Independent Sample t-test.
\end{tabular}

Hormon estrogen selain mempengaruhi kadar estradiol, juga mempengaruhi organ reproduksi salah satunya uterus. Uterus memiliki tiga lapisan penyusun, dan lapisan yang sangat dipengaruhi oleh pola hormon estrogen dan progesteron adalah endometrium (Speroff et al dalam Adinegara, 2006). Induksi hormon estrogen sintetik yang berupa etinyl estradiol pada penelitian ini ternyata memberikan hasil bahwa mencit perlakuan mempunyai rerata tebal endometrium lebih besar dibanding dengan mencit kontrol. Namun perbedaan ketebalan ini tidak signifikan yang menyatakan bahwa hasil analisis pada Tabel I yaitu sebesar 0,2I ( $>0,05)$ 
yang artinya terdapat perbedaan yang tidak signifikan antara tebal endometrium mencit perlakuan dengan kontrol.

Bertambah tebalnya endometrium terjadi karena diasumsikan penambahan hormon yang berasal dari KOK Microgynon. Pada Microgynon tersebut terkandung etinyl estradiol yang merupakan hormon estrogen sintetik dan levonorgestrel yang merupakan progesteron sintetik. Etinyl estradiol yang diinduksikan tersebut mempengaruhi konsentrasi estradiol yang berikatan dengan albumin maupun globulin dalam darah untuk di transportasikan ke seluruh tubuh. Etinyl estradiol mengakibatkan peningkatan ketebalan epitel endometrium, menambah lebar dan panjang diameter pembuluh darah, konfigurasi kelenjar semakin berkelokkelok, stroma semakin longgar (Mescher, 2010). Hal ini berkaitan dengan kadar estradiol di sirkulasi dan konsentrasi maksimum reseptor estrogen di endometrium (Adinegara, 2006).

Reseptor estrogen yang paling banyak ditemukan di epitel maupun stroma endometrium adalah reseptor $\alpha$ (Gruber, 2002). Estrogen berikatan pada RE $\alpha$ stroma yang kemudian akan mengaktifkan faktor parakrin untuk menginduksi mitosis sel-sel epitel. Faktor parakrin berupa epidermal growth factor (EGF) akan teraktivasi oleh ikatan reseptor tirosin kinase yang terdapat pada epitel. Kompleks EGF dan reseptor tirosin kinase tersebut kemudian akan mengaktifkan protein-protein kinase yang terdapat dalam sitoplasma sel. Protein kinase yang teraktivasi diduga berupa mitogen-activated protein kinase (MAPK) yang merupakan sinyal utama pengaktivasi transkripsi maupun translasi, sehingga terjadi sintesis protein (Clarke et al dalam Kusmana, 2007).

Protein hasil sintesis tersebut diperlukan dalam proses mitosis pada sel-sel epitel. Mitosis yang terjadi pada setiap sel epitel kemudian akan menyebabkan epitel tersebut berproliferasi sampai batas optimum, dan dapat dilihat pada ketebalan epitel yang semakin meningkat (Alarid et al, 1999). Penambahan lebar dan panjang diameter pembuluh darah disebabkan karena estrogen berpengaruh langsung terhadap pembuluh darah dengan meningkatkan vasodilatasi dan menghambat aterosklerosis (Mendelsohn \& Karas, 1999). Kemampuan dilatasi ini diperkirakan sebagian karena meningkatnya NO dan sintetase NO (Guetta et al., 1997). Faktorfaktor itulah yang menyebabkan ketebalan endometrium mencit perlakuan lebih tebal dibandingkan kontrol meskipun tidak signifikan. Perbedaan yang tidak signifikan tersebut diasumsikan karena pada kontrol juga masih terdapat estradiol yang secara alami dihasilkan oleh ovarium akibat mekanisme hormon di dalam tubuh sesuai dengan fase pada siklus estrusnya.

Dengan adanya efek-efek yang diakibatkan oleh estrogen tersebut akan berpengaruh buruk terhadap kesehatan reproduksi sehingga untuk mengurangi efek proliferasi endometrium akibat pemberian estrogen, maka perlu dikombinasi dengan progesteron. Mekanisme efek protektif progesteron terhadap hiperplasia endometrium yaitu dengan mengurangi reseptor seluler untuk estradiol. Selain itu progesteron dapat menginduksi enzim yang mengkonversi estradiol menjadi metabolit yang kurang kuat (estron sulfat), mengantagonis sintesis asam deoksiribonukleat, dan mengurangi multiplikasi sel (Taitel \& Kafrissen, 1995). Adapun skema mekanisme kerja hormon estrogen yang diinduksikan tergambar pada Gambar I.

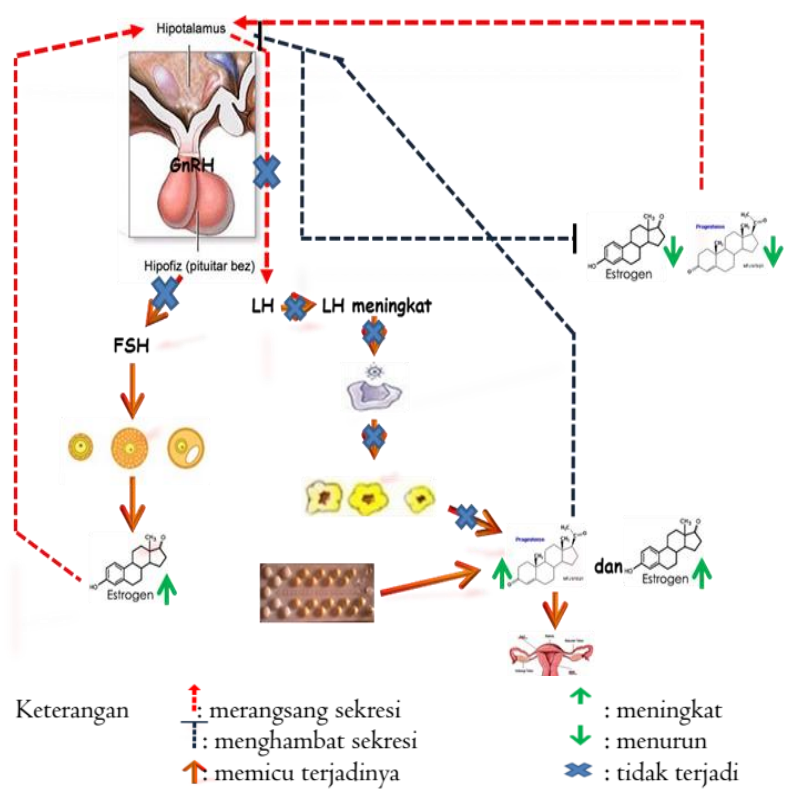

Gambar I. Skema mekanisme kerja hormon estrogen yang diinduksi pada mencit perlakuan

\section{Pengaruh Fase Penyusun Siklus Estrus terhadap Tebal Endometrium}

Fase penyusun siklus estrus terdiri dari 4 fase yaitu diestrus, proestrus, estrus, dan metestrus. Dan pada setiap fase penyusun siklus estrus memiliki karakteristik tersendiri baik itu dilihat dari hasil apusan vagina ataupun ketebalan endometriumnya dikarenakan terjadi fluktuasi perubahan kadar hormon estrogen dan progesteron pada setiap fasenya.

Tabel 2. Rerata tebal endometrium pada setiap fase penyusun siklus estrus $\left(\mathrm{mm}^{2}\right)$

\begin{tabular}{lcccc}
\hline \multirow{2}{*}{ Perlakuan } & \multicolumn{4}{c}{ Tebal Endometrium $\left(\mathrm{mm}^{2}\right)$} \\
\cline { 2 - 5 } & Diestrus & Proestrus & Estrus & Metestrus \\
\hline Kontrol & $0,17 \pm 0,0 \mathrm{I}^{*}$ & $0,2 \mathrm{I} \pm 0,02$ & $0,2 \mathrm{I} \pm 0,02$ & $0,23 \pm 0,0 \mathrm{I}$ \\
\hline Estrogen & $0,2 \mathrm{I} \pm 0,02^{*}$ & $0,22 \pm 0,0 \mathrm{I}$ & $0,22 \pm 0,0 \mathrm{I}$ & $0,2 \mathrm{I} \pm 0,02$ \\
\hline * signifikan pada taraf kesalahan $5 \%$ menggunakan \\
analisis uji One Way Anova
\end{tabular}

Berdasarkan hasil yang ada dapat dilihat bahwa rerata ketebalan endometrium pada mencit perlakuan lebih tebal daripada kontrol, kecuali pada fase metestrus. Namun hanya pada fase diestrus yang memiliki perbedaan yang signifikan terhadap tebal endometrium antara mencit perlakuan dengan kontrol, dan pada fase yang lain hasilnya berpengaruh tidak signifikan terhadap 
tebal endometrium. Hal tersebut diasumsikan karena induksi hormon estrogen yang berasal dari KOK Microgynon tersebut mengandung etinyl estradiol yang merupakan estrogen sintetik dan levonorgestrel yang merupakan progesteron sintetik. Sehingga hormon yang masuk pada mencit perlakuan tidak hanya estrogen sintetik melainkan juga progesteron sintetik. Hal ini juga ikut mempengaruhi ketebalan endometrium pada tiap fasenya. Perbedaan ketebalan endometrium pada fase proestrus dan diestrus dapat dilihat pada Gambar 2.
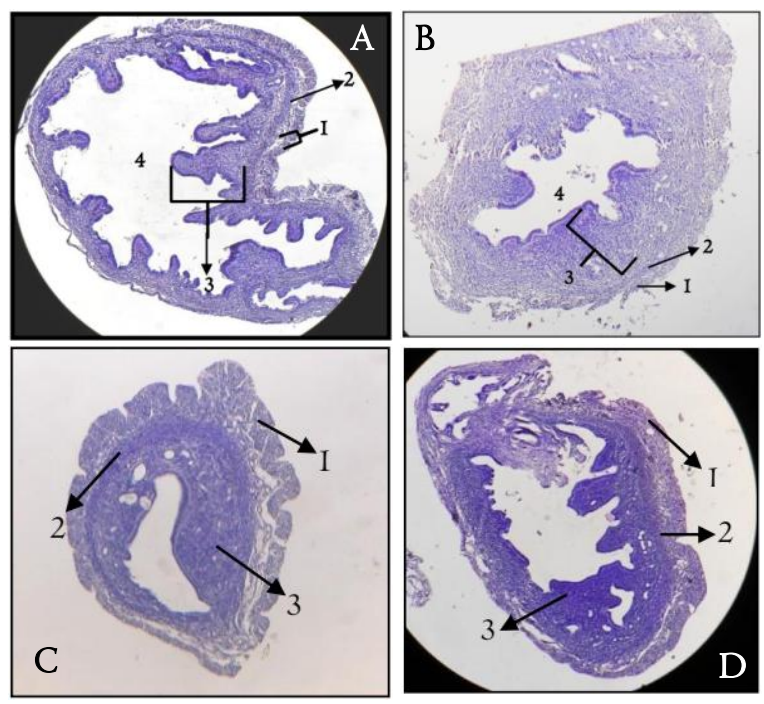

Gambar 2. Penampang membujur endometrium mencit (Mus musculus) (A) fase proestrus pada kontrol, (B) fase proestrus dengan perlakuan estrogen; (C) ase diestrus pada kontrol, dan (D) fase diestrus dengan perlakuan estrogen. Perbesaran I00x. I. Perimetrium; 2. Miometrium; 3. Endometrium; 4. Lumen.

Pada keadaaan normal, fase diestrus merupakan fase ketika corpus hemorrhagicum mengkerut menjadi korpus luteum sehingga produksi estrogen turun dengan cepat sampai batas minimum (Partodiharjo, 1980). Adapun pada mencit perlakuan dimana mencit diinduksi estradiol maka pada fase diestrus yang harusnya estrogen berada pada batas minimum sehingga endometrium menipis, namun karena adanya estradiol yang diinduksikan maka kadar estrogen pada tubuh meningkat dan menyebabkan terjadinya proliferasi. Hal inilah yang menyebabkan terjadinya perbedaan ketebalan endometrium yang signifikan antara mencit perlakuan dengan kontrol. Induksi estrogen yang terus-menerus juga ikut mempengaruhi keadaan endometrium pada fase proestrus dan estrus. Dimana pada keadaan normal, pada fase proestrus dan estrus terjadi peningkatan estrogen yang menyebabkan proliferasi endometrium, sedangkan pada perlakuan, mencit mendapatkan penambahan estradiol sehingga kadar estrogen lebih banyak sehingga proliferasi juga meningkat. Metestrus terjadi ketika pada ovarium terbentuk corpus hemorrhagicum di tempat folikel de Graaf yang baru selesai melepaskan sebuah ovum (Partodiharjo, 1980).
Adapun pada mencit perlakuan dimana progesteron sintetik juga ikut diinduksikan mulai berpengaruh pada fase estrus akhir. Pada fase estrus akhir yang harusnya terjadi peningkatan $\mathrm{LH}$ itu tidak terjadi pada mencit perlakuan. Hal ini dikarenakan progesteron sintetik yang ikut diinduksikan menghambat sekresi $\mathrm{LH}$ dan meningkatkan efek inhibisi estrogen yang mencegah ovulasi (Ganong, 2003), sehingga ovulasi pada mencit perlakuan estrogen tidak terjadi. Terhambatnya sekresi LH ini akan merangsang sel teca interna untuk membentuk corpus luteum dan menghasilkan progesteron secara alami seperti pada keadaan normal, namun karena pada perlakuan estrogen juga mendapatkan induksi progesteron sintetik sehingga kadar progesteron di dalam tubuh mencit perlakuan tersebut meningkat. Peningkatan progesteron yang melebihi normal ini mengakibatkan penurunan jumlah reseptor estrogen di endometrium, penurunan multiplikasi sel, dan meningkatkan kecepatan perubahan I7 $\beta$-estradiol menjadi estrogen yang kurang aktif (Ganong, 2003; Taitel \& Kafrissen, I995), sehingga kelenjar endometrium menjadi atropi dan epitelnya tidak aktif (Suparto, 2007). Hal inilah yang menyebabkan endometrium pada mencit perlakuan lebih tipis dibandingkan dengan kontrol.

\section{Pengaruh Hormon Estrogen Terhadap Panjang Sikhus Estrus dan Tingkah Laku Kawin}

Panjang siklus estrus dan tingkah laku kawin mencit dipengaruhi oleh kondisi hormon dalam tubuh. Hasil yang didapat dari pengamatan ini bahwa rerata panjang siklus estrus pada kontrol dan perlakuan estrogen tidak sama, hal ini dapat dilihat pada Gambar 3. Kekacauan panjang siklus estrus tersebut jelas terlihat pada fase diestrus dan estrus. Dimana pada fase diestrus, mencit perlakuan mengalami fase diestrus tiga kali lebih cepat dibandingkan kontrol dan pada fase estrus mencit perlakuan mengalami fase estrus enam kali lebih lama dibandingkan kontrol. Hal ini diasumsikan dapat terjadi karena estrogen yang diinduksikan pada mencit perlakuan mempengaruhi kinerja hipofisis dalam mensekresikan LH dan FSH sehingga terjadilah kekacauan panjang siklus estrus.

Terjadinya percepatan fase diestrus pada mencit perlakuan disebabkan karena kadar estrogen yang berada di dalam tubuh meningkat tajam. Pada keadaan normal, kadar estrogen pada fase diestrus menurun sehingga merangsang FSH untuk pertumbuhan folikel. Folikel ini akan menaikkan kadar estrogen sehingga terjadi penebalan epitel vagina untuk memasuki fase proestrus (Partodiharjo, 1980). Pada mencit perlakuan, kadar estrogen yang meningkat menyebabkan percepatan penebalan epitel untuk memasuki fase proestrus. Adapun terjadinya fase estrus yang lebih lama pada perlakuan estrogen dikarenakan estrogen yang berikatan pada masing-masing RE $\alpha$ sel epitel vagina lebih banyak dibandingkan kontrol. Pengikatan estrogen pada RE $\alpha$ 
sel epitel vagina menyebabkan diferensiasi sel-sel epitel vagina (Buchanan et al. dalam Kusmana et al., 2007). Hal tersebut yang kemudian menyebabkan keratinisasi pada lapisan bagian atas epitel vagina sehingga siklus estrus berlangsung lebih lama.

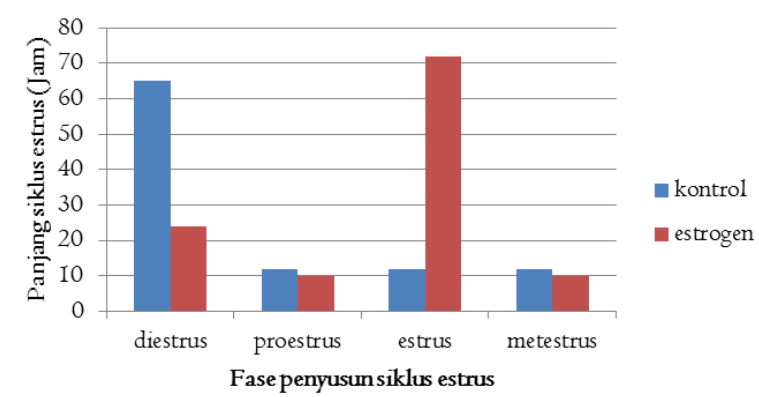

Gambar 3. Panjang tiap fase penyusun siklus estrus pada perlakuan estrogen dan kontrol

Estrogen juga memiliki banyak efek lain. Hormon ini bertanggung jawab atas tingkah laku estrus pada binatang dan mempengaruhi libido pada manusia (Ganong, 2003). Pada pengamatan yang sudah dilakukan, pada kontrol tingkah laku dari mencit-mencit tersebut normal sesuai dengan fasenya dan mereka menanggapi adanya pejantan, sedangkan pada mencit perlakuan, tingkah laku mencit-mencit tersebut hanya awalnya saja mereka menanggapi pejantan karena pejantan tersebut merupakan pendatang baru di kandang mereka, namun setelah berkenalan mencit betina di kandang tersebut tidak respon lagi terhadap kehadiran pejantan, mencit-mencit betina tersebut sibuk sendiri dengan aktivitas masing-masing meskipun mereka ada yang berada pada fase estrus.

Respon pasif dari mencit betina pada perlakuan estrogen tersebut diasumsikan karena ketidakseimbangan kadar estrogen dan progesteron yang berada di dalam tubuhnya sehingga mereka kurang tertarik dengan si pejantan dan lebih memilih untuk melakukan aktivitas yang lain. Perubahan perilaku seksual betina tersebut terjadi oleh karena meningkatnya kadar estrogen dalam darah (Ganong, 1999).

\section{Pemanfaatan sebagai Buku Suplemen Sistem Reproduksi di SMA}

Buku suplemen atau yang biasa disebut sebagai buku nonteks pelajaran berfungsi sebagai bahan pengayaan, rujukan, atau panduan dalam kegiatan pendidikan dan pembelajaran (Pusat perbukuan, 2008b). Hasil penelitian selanjutnya disusun ke dalam bentuk buku suplemen dan dilakukan uji produk. Uji produk dilakukan melalui validasi oleh ahli media dan pengguna. Validasi ahli dan pengguna masing-masing terdiri dari 3 orang yang sesuai dengan kriteria dari Pusat Perbukuan (2008a). Berdasarkan kriteria tersebut, maka ahli yang sudah memvalidasi buku suplemen ini terdiri dari dosendosen Pendidikan Biologi FKIP Universitas Jember yang ahli dibidang materi dan media; sedangkan pengguna yang memvalidasi buku suplemen ini yaitu guru biologi di SMA N 2 Jember, guru biologi di SMA N I Jember, dan guru biologi di SMA N 5 Jember. Validator memiliki kesempatan untuk memberikan penilaian pada produk hasil pengembangan tersebut. Tiap validator mendapat lembar kuesioner yang berisi ranah-ranah penilaian produk yang terstruktur.

Hasil perhitungan kuesioner dari validator ahli materi dan media, jumlah skor rerata yang didapat yaitu 79,55\% yang berarti buku suplemen ini layak untuk digunakan sebagai buku suplemen di SMA dan masyarakat. Hasil dari uji validasi buku suplemen tersebut, validator ahli menyarankan agar memperbaiki dari segi penampilan buku, penulisan istilah, penggunaan bahasa untuk mengkaitkan antar paragraf, dan membuat diagram mode of action (mekanisme terjadinya efek substansi kontraseptif terhadap kinerja hormonal sistem reproduksi wanita) sehingga pembaca lebih mudah untuk memahami dan mengerti alur dari buku tersebut. Hasil dan masukan yang diperoleh dari ahli media menjadi pertimbangan untuk melakukan revisi atau perbaikan terhadap buku suplemen yang telah dibuat.

Adapun jumlah skor rerata hasil perhitungan kuesioner yang didapat dari guru-guru SMA Negeri di Kabupaten Jember yaitu sebesar 84,12\% yang berarti buku suplemen ini sangat layak untuk digunakan sebagai buku suplemen di SMA dan masyarakat. Saran yang diberikan bagi buku suplemen ini adalah materi dan istilah yang disajikan untuk lebih dipermudah sehingga siswa SMA dapat dengan mudah untuk memahaminya. Diharapkan dari buku suplemen ini, siswa SMA mendapatkan pengetahuan yang lebih luas.

Buku suplemen selanjutnya diuji coba pada 40 siswa kelas XI SMA. Berdasarkan uji coba terbatas yang dilakukan, diperoleh hasil keterbacaan dan tingkat kesulitan bahwa buku suplemen yang dikembangkan dan divalidasi mencapai hasil yang baik/positif. Hal itu ditunjukkan dengan $82,50 \%$ siswa menyatakan buku suplemen kontrasepsi hormonal mudah dipahami dan menambah pengetahuan. Hasil tersebut berarti bahwa buku suplemen yang meliputi isi atau materi yang disajikan memiliki tingkat kerumitan yang sederhana dengan bahasa yang mudah dimengerti, sehingga siswa dapat memahami isi dalam buku suplemen. Tingkat keterbacaan sebuah teks disebabkan oleh susunan kalimat, kepadatan kata dalam kalimat, dan kata-kata sulit yang terdapat dalam wacana tersebut. Untuk itu, tingkat keterbacaan suatu bacaan harus sesuai dengan kemampuan membaca pembacanya. Hasil analisis angket respon siswa secara keseluruhan diperoleh rata-rata persentase $87,50 \%$ siswa memberikan respon positif terhadap buku suplemen yang dikembangkan sedangkan hanya 12,50\% yang tidak merespon positif. Hal ini berarti secara umum siswa merespon positif terhadap buku suplemen yang dikembangkan terkait penyajian materi, penggunaan bahasa, pemilihan gambar, dan penyajian lay out. 
Berdasarkan penilaian dan beberapa masukan yang diberikan untuk buku suplemen ini, dapat dikatakan bahwa buku suplemen ini sudah sesuai dengan ciri-ciri dari buku nonteks pelajaran menurut Pusat perbukuan (2008b). Buku suplemen yang telah dibuat dan divalidasi ini termasuk buku nonteks yang fungsinya sebagai bahan pengayaan, buku nonteks pelajaran dapat memperkaya pembaca (termasuk peserta didik) dalam mengembangkan pengetahuan, keterampilan, dan kepribadian. Buku pengayaan pengetahuan merupakan buku yang mampu memberikan tambahan pengetahuan kepada pembacanya, baik yang bersentuhan langsung dengan materi yang dipelajari dalam lembaga pendidikan maupun di luar itu.

\section{Simpulan}

Berdasarkan hasil dari penelitian, dapat diambil beberapa kesimpulan sebagai berikut.

a. Ada perbedaan kadar estradiol pada perlakuan estrogen dengan signifikansi sebesar $0,03(p<0,05)$ terhadap kadar estradiol pada kontrol. Tebal endometrium pada perlakuan estrogen berbeda tidak signifikan $(p>0,05)$ dengan signifikansi sebesar 0,2I terhadap tebal endometrium pada kontrol.

b. Ada pengaruh fase penyusun siklus estrus terhadap tebal endometrium kontrol dan perlakuan estrogen berpengaruh signifikan sebesar $0,04(\mathrm{p}<0,05)$ pada fase diestrus, namun pada fase proestrus, estrus, dan metestrus berpengaruh tidak signifikan $(p>0,05)$ terhadap tebal endometrium.

c. Hasil validasi ahli dan pengguna, uji keterbacaan dan tingkat kesulitan serta angket respon siswa menunjukkan bahwa buku suplemen dari hasil penelitian ini dapat dimanfaatkan sebagai salah satu buku suplemen konsep sistem reproduksi di SMA dengan kriteria layak.

\section{Daftar Pustaka}

Alarid E.T., N. Bakopoulos, N. Solodin. 1999. Moleculat Endocrinology. 13:1522-I534.

Anwar, R. 2005. Sintesis, Fungsi dan Interpretasi Pemeriksaan Hormon Reproduksi. Tidak Diterbitkan. Skripsi. Bandung: Fakultas Kedokteran UNPAD.

BKKBN. 2007. Akseptor KB di Indonesia. Jakarta.

Campbell, Reeche, Mitchel. 2004. Biologi. Edisi Kelima-Jilid 3. Jakarta: Erlangga. Alih bahasa: Wasmen.

Dellmann, H.D. dan E.M. Brown, 1992. Buku Teks Histologi Veteriner II. Third Edition. Jakarta: Universitas Indonesia Press. Alih bahasa: R. Hartono.

Ganong, W. F. 1999. Buku-Ajar Fisiologi Kedokteran E/I7. Jakarta: EGC. Alih Bahasa: dr M. Djauhari Widjajakusumah, et al.

Gruber CJ, Tschugguei W, Schneebeger C, Huber JC. .2002. Production and action of estrogens. N Engl J Med. 346: 340-50.
Guetta V, Quyyumi AA, Prasad A. 1997. The role of nitric oxide in coronary vascular effects of estrogen in postmenopausal women. Circulation 96:2795-280I.

Hartanto, H. 2004. Keluarga Berencana dan Kontrasepsi. Jakarta: Pustaka Sinar Harapan.

Heffner, L. J. dan Schust, D. J. 2008. At a Glance Sistem Reproduksi. Jakarta: Erlangga. Alih Bahasa: dr. Vidhia Umami.

Info Sehat. 05/08/2008. Kontrasepsi Oral KB. Serial online dalam http://www.info-sehat.com/inside_

level2. asp?artid $=7858$ secid $=\&$ intid $=5$. Diakses tanggal 06 Januari 2016.

IPB. 20I0. Dalam http://e library.mb.ipb.ac.id/files/diskI/9/mbipb-I23I242I42 I42I4I2-andreasari-4I3-5-9eb-05-a-i.pdf. Diakses tanggal 20 Januari 2016.

Mendelsohn ME, Karas RH. 1999. The protective effects of estrogen on the cardiovascular system. N Engl J Med 340:I80I-II.

Mendelsohn ME. 2002. Protective effects of estrogen on the cardiovascular system. Am J Cardiol 89(suppl):I2E-I8E.

Mescher, A. L. 20I0. Junqueira's Basic Histology. Twelfth Edition. United States: The McGraw-Hill Companies, Inc.

Murray, K. Robert; Granner, K. Daryl; Meyes, A. Peter; Rodwell, W. Victor. 2003. Biokimia Harper Edisi 25. Alih Bahasa: Adry Hartono. Jakarta: EGC.

Partodihardjo, S. I980. Ilmu Reproduksi Hewan. Jakarta: Mutiara.

Pusat Perbukuan. 2008a. Pedoman Penilaian Buku Nonteks Pelajaran. Jakarta: Departemen Pendidikan Nasional.

Pusat Perbukuan. 2008b. Pedoman Penulisan Buku Nonteks. Jakarta: Pusat Perbukuan Depdiknas.

Suparto, H.I. 2007. Peran Kombinasi Hormon Etinil Estradiol dan Noretindron Asetat dengan Protein Kedelai terhadap Cedera Iskemia Reperfusimiokardium pada Monyet Ekor Panjang (Macaca fascicularis) Hiperkolesterolemik yang di Ovariektomi. Bogor: Institut Pertanian Bogor.

Taitel HF, Kafrissen ME. 1995. Norethindrone-a review of therapeutic applications. Int J Fertil. 40:207-223.

Toelihere, M. R. 1979. Fisiologi Reproduksi Ternak. Jakarta: Angkasa. 